\title{
Media literacy education in colleges and universities: The status quo and the development way of thinking
}

\author{
Tang Yu, Hu Yang \\ Chongqing City Management College,Chongqing 401331, China
}

\begin{abstract}
Key words: Media literacy education in colleges and universities; The status quo; The development approach

Abstract: This paper analyzes the present situation of media literacy education in university and expounds the importance of media literacy education, aiming at the development of media literacy education in colleges and universities conducted in-depth research, combined with the study, puts forward several development strategies, and provides reference for the realization of the whole social media literacy education.
\end{abstract}

\section{Introduction}

Media literacy refers to the public understanding of media literacy. Because of the Internet era, the Internet is filled with all kinds of information, many people lack the information filtering and filtering capabilities, it is not conducive to the effective use of the Internet. College students as the main body of the future society, so it is urgent to cultivate and improve college students' media literacy.

\section{Present situation of media literacy education in colleges and universities}

For the attention of the media literacy level is not high in China, failed to timely to carry out the media literacy education, and even some media professional course in media literacy education of colleges, also only in the form of public class. Until 2004, when the media literacy education problem got the wide attention of scholars. Teaching contents, various colleges and universities media literacy research mostly from the media literacy education content, education status, the meaning of education and education measures. As a result of media education in China started late, so the main research content is the impact of media on students, such as computers and cell phones, did not pay much attention to the influence of some traditional media in the student, thus cause the overall results don't accord with the actual situation, unable to produce effective help to the promotion of students' media literacy. In the teaching methods, the use of traditional classroom knowledge to explain the way to carry out media literacy education, and it is difficult to improve the effect of media literacy education. The lack of adequate faculty, a lot of media literacy are made by other subject teachers part-time job as a teacher, the lack of a clear understanding of media literacy. In terms of curriculum system, mainly adopts some news media professional media literacy teaching content, can not be combined with the actual situation of school students to carry out media literacy education. Through the way of questionnaire, randomly selected three vocational colleges in Chongqing issued 900 questionnaire investigation and statistics, which fill in the personnel structure for the following figure, through the analysis of the survey structure, we can get the general understanding of media literacy among the three college students: 


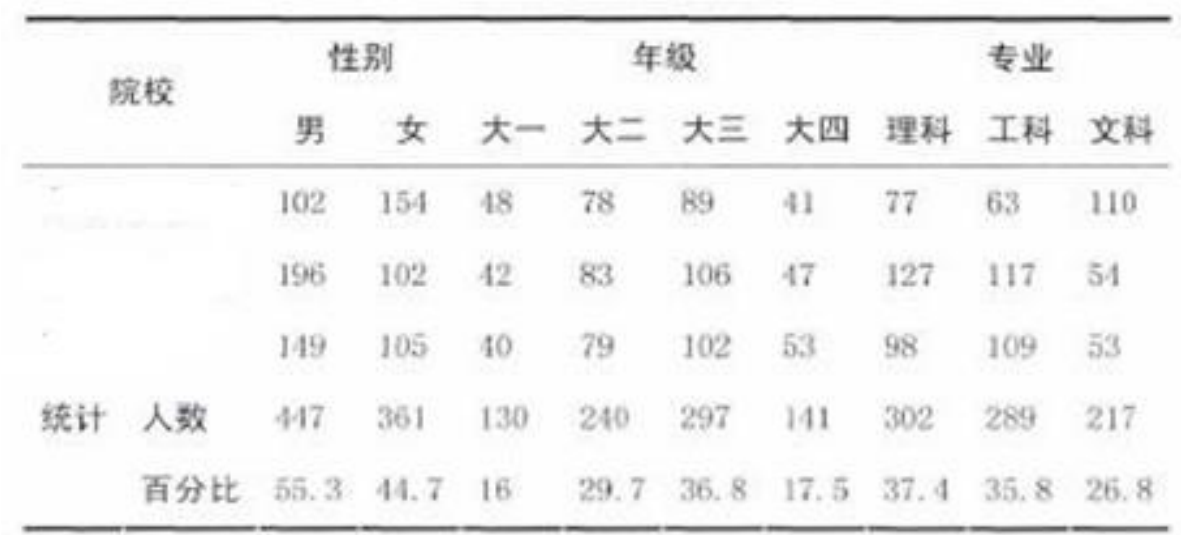

Found when investigating the concept of media, the first is how familiar ways, such as left. 三所高校大学生样本对媒介素菜了解情况
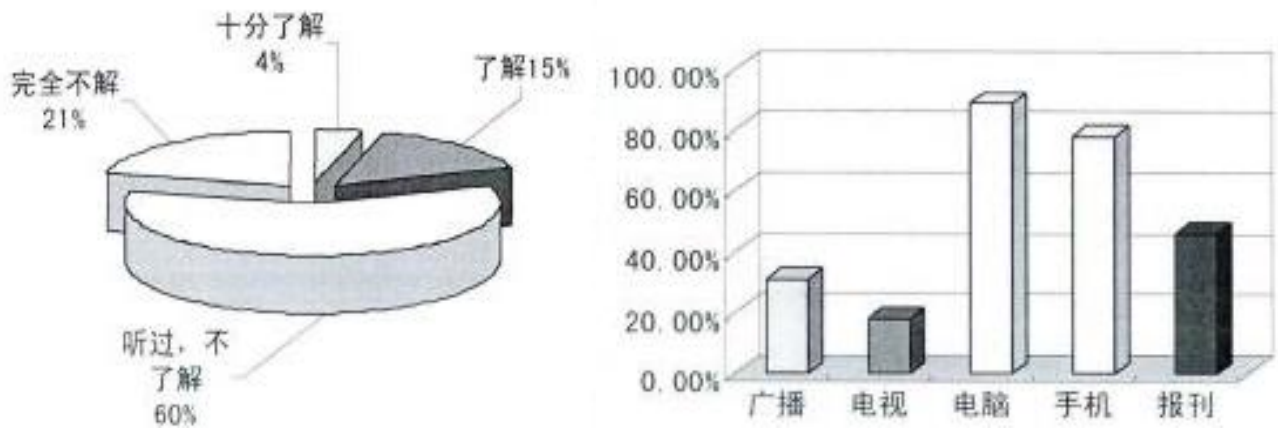

The second is when the question and answer "what do you think of the current college students is the lack of media literacy", almost $95 \%$ of the students think their media literacy is lack. And asked "the media literacy improve the comprehensive ability to promote the benefits ", nearly $60 \%$ of people think is good, about $30 \%$ of people don't know, the rest of the people claim is not good. In view of the "media access to information channels as well as the medium of information communication consciously", only about $20 \%$ of the students can more consciously in media access to information. In the survey, only $30 \%$ of students take the initiative to media information retrieval. In the media access, access method such as the right.

\section{The goal of media literacy education in colleges and universities}

\subsection{For the education activities in colleges and universities to establish goals}

Any education activities are around the education target. The media education into youth education, is in line with the time development education strategy, is the new period of the party and the state's expectations of students. Second is the basic task of education in colleges and universities, colleges and universities the main teaching task is to improve the students' knowledge accumulation and the thought moral education of students at the same time, make the education of talents has certain innovation practice ability, contribute to the development of the society. And media education is also to promote the all-round development of students, the media education as students teaching task, can realize the perfection of the whole education system and update. Finally is carried out in efficient media education is the inevitable demand of the development of modern media, along with the development of multimedia technology application, information age has been widely used in our daily work life each domain. The student is now one of the most popular people contact media, is also the core force of the future development of the socialist cause, to improve college students' media literacy can effectively improve the media literacy of society as a whole. When to set media education target, must take into account the students' real media literacy levels, according to the actual situation of education to point out the emphasis in education work.

\subsection{Meet the requirements of education goals}

For media literacy education, first of all, can let students have a correct understanding of media, to 
feel the importance of media literacy in the information age, develop students' learning and innovation consciousness, forming a correct health concept of media. When the student to the media knowledge has certain master, can improve students' right of media in a variety of information screening and discrimination, learn to effectively use the media power. Because of the media information rich and colorful, students easy to indulge in the network, through the media literacy education can make students for the media have a sober understanding, promote the development of students' mental health. When students to participate in the activities of the medium, can effectively maintain the traditional virtues of the Chinese nation, enhance the students' moral accomplishment, consciously abide by relevant laws and regulations, strengthen the concept of law-abiding.

\section{The development approach of media education colleges and universities}

\subsection{Strengthen the consciousness of education}

Strengthen the consciousness of media education, in the direction of media literacy education to the modernization. The basic qualities that a modern citizen moral accomplishment is more than just the humanities accomplishment, the legal system, also need to add the media literacy in the basic quality of modern citizens. Schools need to recognize the urgency of media education correctly, attach importance to students' media education status, the media education in the position to see equal to those of other disciplines. When the school is carrying out media reform, can set up a special department of media literacy education, equipped with excellent faculty team, ensure the enough development funds. According to the actual situation of school formulate detailed rules for the media literacy education, investigation and evaluation regularly on the progress of the media literacy education, timely adjustment of teaching methods, to ensure the smooth progress of media education.

\subsection{Rich education content}

Every country in the world of media education idea and the way are different. Media education content showed a trend of diversification, as a result of media education development in our country lags far behind the western countries, so copying western teaching content is difficult to obtain ideal teaching effect. On media education content design, need on the premise of the actual situation of our country and in the media literacy education concept education, ability education, psychological education, moral education and legal education, formed with characteristic of our country media education content, makes the media education in our country has a good effect.

\subsection{To improve the education methods}

To ensure the smooth progress of media literacy education, must have a perfect method of media literacy education. Students have a high appetite for fresh things, but also for the media have a preliminary understanding. In the media literacy education, must be combined with the students' interests, can make the media literacy education to achieve good teaching effect. When the teacher in teaching, can start talking about the Internet, from the aspects of structure, function and so on to let the students have a comprehensive understanding of the Internet. According to the use of students, Such as playing games, check information, chat, etc. to make evaluation, to teach students some skills for new Internet applications, to improve students' interest in learning at the same time, enhance the students' practical ability and the use of the Internet more ability. Education teaching do not have a fixed set of method, each teacher has their own unique teaching idea. The teacher in the teaching, can effectively combine the teaching content and students' psychological characteristics to carry out teaching activities, guides the student to the correct study practice to explore, to enhance their teaching effect.

\subsection{The construction of teachers}

The teacher's own media literacy directly affects students' study effect, our country at present most of the media literacy of university teachers strength weak, just news related to the student's media literacy education more seriously. Want to build up the professional team of media literacy education, first of all, with the help of news professional faculty, mobilize the initiative of their 
media literacy education, in addition to professional knowledge, to study the media literacy education for our teaching methods, combined with modern means of science and efficient to carry out the media literacy education, and will promote research results to other school. To strengthen the media literacy of the journalism teacher training, provided a basis for conducting media literacy education.

\subsection{Perfect curriculum system}

In the efficient development of media literacy education, first of all must have a specialized curriculum pattern, according to the present teaching situation in our country, should not be limited to a single kind of curriculum system, and should make diversified curriculum system. Such as the economy is relatively developed city, media education courses may be offered, other teachers are not very strong area, the penetration of media literacy education in other disciplines, such as adding content of media literacy education in the ideological and moral course. Second to add the corresponding media education teaching materials, such as books, notes and related multimedia software and so on. The teaching material has a very important role in the teaching, is a bridge connection between teachers and students, is the carrier of knowledge. Under the lead in the ministry of education, organize professional good news media literacy education experts and teachers to write. Also perfect for media literacy education evaluation, reasonable evaluation mode can effectively supervise and urge the teacher students improve education quality.

\section{Conclusion}

Efficient media literacy education shoulder the heavy burden of improve the whole social media literacy, schools should strengthen the importance of media literacy education, through a series of reform measures to improve media literacy teaching content, improve the teaching quality of media literacy, and in turn strengthen the student's media literacy, for the improvement of the whole social media literacy to lay a good foundation.

\section{Acknowledgements}

This article is the result of 2015 Chongqing Education Science "12th Five-Year" planning topics. Project number:2015-ZJ-044.

This article is the periodical achievement of Scientific and Technological Research Program of Chongqing Municipal Education Commission, which studies the impacts of pop culture on university students' cultural identity (KJ1503207).

\section{References}

[1] Li Xing. Contemporary university students media literacy education research [D]. Shanxi Agricultural University, 2013.

[2] Wang Baoyin. Media literacy education of college students [D]. Hebei Normal University, 2015. 